\title{
America's Great Malaise and what to do about it
}

\author{
Joseph E. Stiglitz ${ }^{*}, 1$ \\ Department of Economics, Columbia University, 3022 Broadway, New York, NY 10027, United States
}

Received 3 January 2016; received in revised form 20 February 2016; accepted 15 April 2016

Available online 26 May 2016

Keywords: America's malaise; Supply-side experiment; Growth; Inequality; Aggregate demand; Financial regulation

\section{Introduction}

While we celebrate the beginning of the end of the era of zero interest rates, the US economy can hardly be called healthy. GDP is some $15 \%$ below what it would have been had the growth rates that prevailed between 1980 and 1998 continued. The percentage of the working-age population employed has increased only slightly since the "recovery" began, and is still lower than it was in the early 1980s, when women were entering the workforce en masse. ${ }^{2}$ Median real (household) income is less than $1 \%$ higher than it was in $1989 .{ }^{3}$ Real wages at the bottom are lower than 60 years ago. ${ }^{4}$ More than a fifth of African-American youth are unemployed. ${ }^{5}$ All of this, 8 years after the beginning of the last recession.

* Tel.: +1 212854 0334; fax: +1 2126628474 .

E-mail address: jes322@columbia.edu

1 University Professor, Columbia University. Paper presented to the American Economic Association, San Francisco, January 3, 2016. Financial support of INET (the Institute for New Economic Thinking), and the Ford Foundation Inequality Project at Roosevelt Institute, supported by the Ford and MacArthur Foundations and the Bernard and Irene Schwartz Foundation, is gratefully acknowledged, as is research assistance from Debarati Ghosh and Eamon Kircher-Allen. A shortened version of this paper, "How to Restore Equitable and Sustainable Economic Growth in the United States", is to be published in the May issue 2016 of the American Economic Review.

${ }^{2}$ See the St. Louis Fed's presentation of Bureau of Labor Statistics data, available at https://research.stlouisfed.org/ fred2/series/EMRATIO.

3 Census Historical Income Table H-6.

${ }^{4}$ Minimum wages (adjusted for inflation) were some $24 \%$ lower than they were in 1968. Real wages at the 10th percentile are below what they were in 1980, while those at the 30th percentile have barely increased. See statistics from the Economic Policy Institute, available at http://www.epi.org/publication/why-americas-workers-need-faster-wage-growth/.

5 The unemployment rate for African Americans aged 16-24 was 20.7\% in July 2015, the last month for which the Bureau of Labor Statistics reported that specific data. See http://www.bls.gov/news.release/youth.t01.htm. 
The underlying problem is a lack of aggregate demand. Think about where the economy was in 2007: while aggregate demand and supply were roughly in balance, demand was supported by an unsustainable housing bubble. The bottom $80 \%$ was spending $110 \%$ of their income. It was inevitable that the (personal) savings rate would increase from its record 2005 low of $1.9 \%$; even now, at $5.4 \%$, it is below what one would think of as a normal, sustainable level. ${ }^{6}$ Meanwhile, America has been experiencing its own mild form of austerity, with public sector employment some 500,000 below 2008, while with normal expansion, in line with the growth of the population, it would have been more than 2 million higher. ${ }^{7}$ A weak global economy - growth in 2015 was the weakest of any year this century, save the recessions of 2001-2002 and 2008-2009 ${ }^{8}$ — and a strong and strengthening dollar do not bode well for exports. With C, X, and G weak, it's perhaps not a surprise that investment is too. Globally, the flood of money from monetary easing, including QE, has not led to the hoped-for increase in investment.

\section{Misdiagnosis of the great recession}

Eight years ago, there was a misdiagnosis of the recession. Some thought it was a financial crisis: the banks had been reckless in lending. They needed to be recapitalized and reformed. That has largely happened: Dodd-Frank, though far from perfect, was at least a start; and bank balance sheets have largely been restored. Still, the economy remains weak.

Partly, this is because the Fed and Administration focused on the big systemically significant banks, not on local, community, and regional banks which are disproportionately responsible for small and medium-sized enterprise (SME) lending. While no one such bank alone may be systemically significant, in the aggregate, reduced lending to SMEs is systemically significant. Focusing more on repairing the credit channel would have meant that more of the increased liquidity went to increase investment rather than to increasing prices of existing assets, creating asset bubbles.

Some thought the downturn was a balance sheet recession; and again, the recovery from such recessions is slow, because balance sheets recover slowly. Balance sheets were hurt, but this downturn was more than a balance sheet recession. The balance sheets of large corporations are sufficiently good that dividends and CEO pay are robust. These corporations earn large fractions of their income abroad, and until rather recently, emerging market growth has been strong. Large American corporations are sitting on almost two trillion dollars of cash. It is not corporate balance sheets or their access to finance that is holding them back from investing: it is lack of demand.

\subsection{Underlying problems}

There are at least five related underlying problems.

The first is inequality. The increase in inequality has weakened consumption from what it otherwise would be. Those at the top spend a smaller percentage of their income than the rest.

\footnotetext{
${ }^{6}$ Bureau of Economic Analysis data as reported by the St. Louis Fed at https://research.stlouisfed.org/fred2/series/ PSAVERT.

7 Based on Bureau of Labor Statistics data at http://www.bls.gov/schedule/archives/empsit_nr.htm.

8 IMF World Economic Outlook, October 2015, available at https://www.imf.org/external/pubs/ft/weo/2015/02/.
} 
The second is structural transformation: the United States has been moving from a manufacturing to a service sector economy. Global manufacturing employment is in decline, and with globalization, the US will be seizing a declining share of that employment, specializing in skill- and capital-intensive niches. For a while, construction masked what was going on; but the real estate bubble was but a short-term palliative. Among the service sectors that should be taking up the slack are education and health. In both, government rightly plays an important role, and austerity has constrained the ability of the government to play the role which it should. More generally, for understandable reasons related to capital market imperfections, markets on their own do a poor job at managing the kind of large structural transformation that is needed. ${ }^{9}$

These structural changes pose several challenges. The new economy may be less capitalintensive, so that the investment needed to support a given growth in GDP may be smaller. Older workers especially may be ill-prepared for the new economy. With the aging of the baby-boomers, a larger fraction of workers are older; this means that the societal costs of not retooling - of simply accepting their obsolescence - are higher.

The third is the financial sector. Reform discussions have focused on preventing the sector from imposing harm on the rest of society - preventing negative externalities, as a result of predatory lending, abusive credit card practices, market manipulation, exploitation of uninformed consumers, taking advantage of information asymmetries and market power, etc. Little attention has been paid to ensuring that the sector fulfills the important societal roles that it needs to perform if the economy is to function well, e.g. providing SME and housing finance, managing retirement accounts, and running the payments system at low transactions cost. Almost a decade after the breaking of the housing bubble, almost all mortgages continue to be underwritten by the government. The mortgage securitization process is broken, and for good reason - there are inherent flaws in the information flows associated with it, that opened up unprecedented opportunities for abuse and fraud, which were taken advantage of by the credit rating agencies, investment banks, and mortgage originators. ${ }^{10}$

The fourth is underinvestment by government in infrastructure and technology, both of which are complementary to private capital. With government support of basic research (as a percentage of GDP) lower than it was a half century ago, ${ }^{11}$ the wellspring of ideas driving new innovations to increase productivity may be drying up.

The final is political: continuing austerity, in the presence of inadequate private demand, and in the face of the other problems I have delineated, effectively ensures an underperforming economy.

\section{Restoring shared prosperity}

The solutions to the economy's doldrums, alternatively referred to as the Great Malaise and the New Mediocre, follow directly from the diagnosis. In the discussion below, I put aside questions

\footnotetext{
9 See Delli Gatti et al. (2012).

10 The Financial Crisis Inquiry Commission called attention to many of these problems. (See The Financial Crisis Inquiry Report, January 2011, https://www.gpo.gov/fdsys/pkg/GPO-FCIC/pdf/GPO-FCIC.pdf.) Problems have been made worse by the difficulties of enforcing contractual provisions associated with putbacks, whereby those originating or selling "defective" mortgages agreed to take back these mortgages when the defects were discovered.

11 Though higher than it was in 1975. From the National Science Foundation, http://www.nsf.gov/statistics/2015/ nsf15324/pdf/tab1.pdf, and the Bureau of Labor Statistics.
} 
of political feasibility. Two policies that are not likely to work are monetary policy and new trade agreements. They may in fact exacerbate the economy's problems.

\subsection{Monetary policy}

Monetary policy (in the absence of the deeper reforms to the financial system to be described below) alone has proven insufficient to restore growth; indeed, recent policies have arguably increased inequality (Stiglitz, 2015a). Low interest rates encourage the use of relatively capitalintensive technology, making a "jobless" recovery more likely. The zero lower bound (ZLB) does not adequately explain the limitations on the efficacy of monetary policy; if it did, the government could use tax policy (increasing consumption taxes over time and decreasing investment tax credits) to change intertemporal prices in the same way that lower interest rates would. Real interest rates have been negative $2 \%$, and a further decline to negative $3 \%$ or $4 \%$ would, I suspect, have minimal effects. With monetary policy moving off the ZLB, this will no longer be an excuse.

Large corporations are sitting on a couple of trillion dollars of liquid funds. The problem is access to finance by SMEs. When the banks were bailed out, the focus was on the large, systemic banks. But there can be systemic effects from weaknesses in a multitude of small banks; their weakness translates into the lack of credit for SMEs, because these banks are disproportionately focused on such lending, rather than speculation, derivatives, and global finance.

\subsection{Trade agreements}

Proposed trade agreements may make matters worse: the United States imports labor-intensive goods, and exports capital-intensive goods, so that any reasonably balanced trade agreement will reduce employment. Moreover, investment provisions that reduce the risk of investing abroad encourage shifting production abroad.

There is, however, an agenda that will work to restore growth:

\subsection{Climate change}

Imposing a carbon price, reflecting the social cost of emissions, would significantly stimulate investment, especially if finance was available for such investments. To ensure a level playing field, we might have to impose cross-border adjustments. A carbon tax would simultaneously raise substantial revenues needed to finance the public investments described elsewhere in this paper.

\subsection{Infrastructure and technology}

With the real interest rate at which government can borrow much lower than the returns on public investments in infrastructure and technology, such investments would increase growth both today and in the future. And since much of this public investment is complementary with private capital, private investment will be stimulated, providing a further spur to the economy. Institutionally, this investment could be financed through an infrastructure bank: the European Investment Bank has proven to be an effective way of financing cost-effective infrastructure on a large scale. 


\subsection{Ending austerity}

The notions of expansionary contractions (Alesina \& Ardagna, 2010) and that there is a critical threshold above which debt lowers growth have been discredited (Baker, 2010; Herndon, Ash, \& Pollin 2014; Jayadev \& Konczal, 2010; International Monetary Fund, 2010). Austerity hurts now, and in the future: hysteresis effects mean even potential growth is lowered (Reifschneider, Wascher, \& Wilcox 2013). Government should take a balance sheet perspective: borrowing for investments can actually improve the country's "net worth." We have many investments with real returns far higher than the current negative cost of capital. Government should employ capital budgets that allow it to borrow against investments. And when fiscal rules are adopted, they should be formulated with an eye to the different contingencies that the economy might face. When I was on the Council of Economic Advisers, the Republicans put forward a balanced budget amendment to the Constitution, which would have proscribed government from ever running a deficit. (Ironically, since the proposals were made, the major violators of these strictures have been Republican-controlled Congresses.) We opposed it strongly, recognizing that one cannot tell future economic circumstances. We believed that if the economy again had a major economic downturn, it would be better to run a deficit than to see massive unemployment. We prevailed, but barely. Since then the case against such poorly designed strictures has increased. It is now widely known that monetary policy cannot restore the economy to full employment, even if interest rates are decreased to zero (or even become negative). And it cannot do it even over a period of years. More thoughtful strictures, therefore, provide escape clauses: the government should be allowed to run a deficit if (a) there is significant unemployment and (b) monetary policy is unlikely to be ineffective (because of the ZLB) or has proven itself ineffective.

If fiscal deficits are a concern, the balanced budget multiplier means that increasing taxes in tandem with investment spending increases GDP now and in the future. If taxes are raised on the rich, and the spending goes for investments in education, technology, and infrastructure inside the country, the balanced budget multiplier can be quite large.

\subsection{Fighting inequality}

Earlier we explain the role that increased inequality plays in dampening growth. An agenda to reduce inequality has to be shaped by an understanding of the forces that give rise to it. Four hypotheses have emerged: (a) The conventional economist focuses on the forces of supply and demand; how shifts in the demand and supply curves in recent years seem to have enriched the top at the expense of the rest. In this perspective, the task of reducing inequality is to identify the forces, change them, and perhaps identify forces that would move demand and supply curves in a more salutary way. This approach has some weight, but as I explain below, much of the country's high and growing inequality is not just the result of ordinary shifts in supply and demand curves in competitive markets, such as those brought on by changes in technology, education and globalization. It is true that changes in technology have increased the premium on those who have obtained at least 4 years of higher education. This helps explain the disparity between collegeand high school-educated workers. The magnitude of this differential is, of course, affected by the fraction of young people graduating from college; the larger that number, presumably, the smaller the "education premium." Interestingly, the US has done a much poorer job than some other countries in increasing the ratio of college graduates to high school graduates. From 2000 to 2012 (latest available data), the ratio of citizens aged 25-64 with tertiary education to those 
with only secondary education increased by an average of $50 \%$ in OECD countries and well over $100 \%$ in Korea and Norway, compared to just $39 \%$ in the United States. ${ }^{12}$

Similarly, globalization has integrated into the global marketplace in effect more than a billion relatively uneducated workers, and the prediction of Stolper and Samuelson (1941) is clearly that that will be bad for unskilled workers. But other countries have opened up their markets, with less adverse effects.

Why are the adverse effects so much larger in the United State? It is perhaps partly because the country has not done as good a job at educating and retaining our workers, to move up the skills ladder. Perhaps at the same time that the country was hit with this onslaught of "opening" there were other changes: we began a process of rewriting the rules of the game and the way they are implemented. Markets don't exist in a vacuum, and the way they are structured affects market efficiency, distribution, and how markets function (Stiglitz Joseph, Abernathy, Hersh, Holmberg, $\&$ Konczal, 2015). The new rules weakened unions, and prevented them from playing the role that they might have played in advocating for better retraining; they might even have slowed the pace of wage decline. There was a vicious circle. Because of globalization and the weakening of unions, unions could not strongly protect workers, which led to a loss of interest in unions, which weakened unions further. What happened in the US contrasts with what happened in an even more open economy-Sweden-where strong unions succeeded in compressing wages, inducing firms to engage in productivity-enhancing investments in technology and people, supported by government programs. What has happened in the United States has thus made workers particularly vulnerable to an increase in imports. Recent studies show that an increase in Chinese imports results in a decline in incomes and an increase in unemployment in communities producing similar products (Autor, Dorn and Hanson, 2013).

The rules of the market game were rewritten beginning in the late 1970s. There were two key strands of reforms: lowering taxes, especially at the top; and deregulating — stripping away regulations especially in the financial sector, culminating in the repeal of part of the Glass-Steagall Act of 1933 by the Financial Services Modernization Act of 1999, ensuring that risky derivatives would not be regulated. Larry Summers, the Secretary of Treasury at the time, hailed this as his most important achievement. The story of the consequences of these "reforms" for the subsequent slowing down of the US economy and the increase in its volatility is now well-told. ${ }^{13}$ But the role of the changes in the rules for the increase in inequality is not as widely recognized. (See Galbraith, 2012). A larger proportion of those in the Fortune 100 are from finance. Particularly disturbing were the large bonuses the bankers received even as they led the economy into the Great Recession - through behavior that should have been reprimanded and punished, not rewarded. Income that is unrelated to an individuals' contributions is often referred to as rent. The rent a landlord receives on a farm is not the result of the farmer's own effort, but simply accrues to the owner of the farm by virtue of his ownership.

There are good arguments to believe that there has been an increase in rents - accruing especially to those at the top. The increase in rents arises in part from changes in technology - network technologies can naturally give rise to monopoly power. The move to local servicebased economies may provide more scope for rents than global manufacturing, and to changes in rules and how they are enforced - Chicago school doctrines have made it more difficult to win cases of predatory pricing. Urban congestion can drive up land rents, but I believe much

\footnotetext{
12 OECD education indicators.

13 See, e.g. Stiglitz $(2003,2010)$.
} 
of the increase in land rents is a result of the way the financial sector has been allowed to work.

Increases in rents (no matter how arrived at) can help explain the anomaly of an increased wealth/income ratio accompanied by a decrease in the ratio of productive capital to income, as well as some of the marked changes in distribution (Stiglitz, 2015c). Empirical work showing that increases in tax rates at the top do not lead to lower growth are consistent with the rent-seeking hypothesis. ${ }^{14}$ The rules can and should be rewritten, in ways that promote equality, growth, and employment and reduce exclusion. For instance, taxes on rents (both those associated with land and natural resources) would increase investment in productive assets and again provide substantial revenues. Rewriting the rules would address the marked disparity between the growth in labor productivity and real wages that has opened up during the past third of a century. Eliminating the preferential treatment of capital gains - especially on land - and other forms of return on capital would reduce another set of distortions in the economy, increase the overall progressivity of the tax system, reduce inequality, and generate substantial revenues (Stiglitz, 2015b).

Piketty (2014) has put forth still another hypothesis, focusing on differential savings rates between the capitalists and the rest, under the condition that the rate of return exceeds the rate of growth. Earlier (Stiglitz, 1969) as well as in more recent work (Stiglitz, 2015c), I had explored the long-term distribution of wealth that arises under alternative savings hypotheses, including those considered by Piketty. Though there are some special cases in which there can be divergence, in general, an equilibrium wealth distribution emerges. ${ }^{15}$ But that equilibrium can be affected by government policies. The US has a regressive tax system at the top, and that naturally leads to more inequality. Tax reforms that raise the taxes on capital at least to that on labor - and to higher levels for short-term capital gains - would lead to lower equilibrium wealth and income inequality. So too would better public education. Such policies not only lead to more equality, they lead to more equality of opportunity, by reducing the intergenerational transmission of advantage.

Ironically, many of the provisions designed to spur the economy didn't do that — but did spur inequality. Lowering taxes on corporations does not lead to more investment; most investment is debt-financed, and lowering the corporate income tax thus raises the after-tax cost of capital. ${ }^{16}$ Lowering taxes on dividends encouraged firms to pay out dividends immediately, so that when a good project comes along, there may not be the financial wherewithal to undertake it. ${ }^{17}$ The preferential treatment of capital gains, say on land, may divert valuable resources - including human resources — to financial speculation, again lowering long-term productivity.

Reduced inequality itself would improve economic performance, not just in the short term, but also in the long (Ostry, Berg, \& Tsangarides, 2014; Stiglitz, 2012).

\subsection{Reforming the financial sector and corporate sector}

Among other reforms that are needed and could be accomplished by rewriting the rules are those that shape the financial sector. Sitting between long-term savers and long-term investment

\footnotetext{
14 Piketty et al. (2014).

15 More particularly, the rate of return on capital is endogenous, and in the long run, if $\mathrm{s}$ is the savings rate of capitalists, $r$ the rate of return, and $g$ the growth rate, $\mathrm{sr}<\mathrm{g}$ (while Piketty's growth of inequality was predicated on just the opposite). His explanation of the growth of wealth as being a result of savings is also unpersuasive. Looking at savings from the national income accounts, the capital income ratio is actually declining. The wealth income ratio is increasing because of the increase in the capitalized value of rents.

16 Stiglitz (1973).

17 Korinek and Stiglitz (2009).
} 
needs are shortsighted financial markets, which have been more active in disintermediating corporations than in disintermediating between savers and investors. Reducing financial sector-induced distortions in the allocation of human and physical capital would also contribute to long-term growth.

One of the well-identified weaknesses in the US corporate sector is its short-termism: a focus on the short term makes it difficult to make long-term investments in people and technology. The financial sector, with its focus on quarterly returns, encourages short-termism. In Rewriting the Rules, we describe policies which would encourage firms to think more long-term. Tax laws have encouraged executive compensation by stock options, and typically, the executives do not have to hold the stock for the long term. If they did, that would encourage more long-term thinking. As it is, with financial markets thinking short-term, so do executives. They do what can be done to get the stock price up now. The shortsighted market puts more weight on the appearance of increased profits that arises from saving costs today (by not investing in workers' training, by undermining worker loyalty, by dismissing workers the moment there is a downturn) than on the potential for savings costs in the future, when the economy recovers. Had they retained their best workers, they would have a productive and loyal labor force that would not need retraining.

There are also reforms to corporate governance - disclosure requirements that would enable shareholders to see more clearly the exorbitant and often hidden compensation that executives receive (e.g. valuing the stock options correctly). Other corporate government reforms would enhance the say that shareholders get in the pay that executives receive. A third reform is to change voting rights - to loyalty shares, with long-term investors getting more weight than short-term investors. Finally, recognizing the large impact that corporations have on the many stakeholders of the corporation, and that shareholder value maximization does not lead in general to Pareto Optimal outcomes (except in the totally unrealistic case of perfect markets) ${ }^{18}$, the legal framework for corporations needs to move away from shareholder maximization to a broad stakeholder perspective, with representation on boards of workers and those from the communities in which corporations operate. Broader reforms in the rules governing pension funds and their holdings would be useful: while it is important that they have a fiduciary responsibility, that should be interpreted to include the right to exclude from the portfolios companies that have deficient corporate governance, bad worker relations (evidenced by the absence of unions), or act in other ways inconsistent with general norms of corporate social responsibility (e.g. adverse environmental impacts).

\subsection{Structural transformation}

More than a half century ago, our economy needed to make another structural transformation, from agriculture to manufacturing. (Delli Gatti et al., 2012a, D, M, B, A, \& J, 2012). The market failed to manage this transformation smoothly. Costly mobility trapped labor in the agricultural sector. It was government action, through spending during and after World War II (including through the GI Bill), that brought about the transition. Once again, the government needs to take an active role, including through more active labor market policies. Such policies only work, however, if there are jobs for the retrained workers. The policies described above will help ensure that these are created.

18 Grossman and Stiglitz $(1976,1977)$. 


\subsection{Reforming global financial architecture}

The global context is, however, markedly different today than it was 70 years ago. While, as I explained above, the proposed trade agreements may be counterproductive, reforms in the global financial system could help. The role of the dollar as the reserve currency is not only an anachronism, but leads to a stronger dollar, impeding exports. A global reserve system, as suggested by Keynes and a recent UN Commission that I chaired, would lead to greater global stability and a stronger American economy (Greenwald \& Stiglitz, 2010; Stiglitz and UN, 2010).

\section{Concluding remarks}

The malaise in which the country has been for 8 years is likely to continue unless something changes. But it is important to recognize that it is not an inevitable consequence of economic laws and the changes in technology that we have faced in recent decades. A third of a century ago, the country embarked on a supply-side experiment of lowering tax rates and liberalization/deregulation. Though it was recognized that this would lead to more inequality, the hypothesis was that it would enhance growth, and that as a result everyone, or almost everyone, would be better off. The predictions didn't come true. And when that happened, rather than rethinking the experiment, the country doubled down. A third of a century later we have seen the results. Instead of almost everyone finding better-than-ever prosperity, almost everyone has experienced near stagnation: only those at the top have flourished. Growth for the economy as a whole has slowed. Rather than higher household savings rates, they decreased to near zero, and are still far lower than they were before we began the "experiment." Labor force participation too is down to levels not seen until before the "experiment." The rate of productivity increase is down — recently, very much so. With inputs down and productivity down, it was inevitable that growth would slow.

The thesis of this paper is that at the center of current problems is a lack of aggregate demand. But we have also explained that the ideologically driven attempt to improve supply had just the opposite effect. We needed reforms in corporate governance and financial regulation and in taxation, but the reforms that are actually undertaken are often just the opposite of what is needed.

These and other supply-side reforms (like improving competition policy) would put us on a path for higher growth in the future. But supply side reforms without demand side measures could move people to unemployment and lead to increased inequality. It is only by undertaking sufficiently strong demand side reforms in conjunction with the appropriate supply side reforms can we simultaneously grow today, grow tomorrow, and address a host of other social, economic, and environmental problems.

This paper has outlined an agenda that would enable us to restore robust equitable and sustainable growth.

\section{References}

Alesina, A., \& Ardagna, S. (2010). Large changes in fiscal policy: taxes versus spending. In Jeffrey R. Brown (Ed.), Tax policy and the economy (24) (pp. 35-68). Cambridge, MA: National Bureau of Economic Research Books.

Autor, D. H., Dorn, D., \& Hanson, G. H. (2013). The China syndrome: local labor market effects of import competition in the United States. American Economic Review, 103(6), 2121-2168.

Baker, D. (2010). The myth of expansionary fiscal austerity. Center for Economic and Policy Research Issue Brief. October Delli Gatti, D., Mauro, G., Bruce, C. G., Alberto, R., \& Joseph, E. S. (2012a). Mobility constraints, productivity trends, and extended crises. Journal of Economic Behavior and Organization, 83(3), 375-393. 
Delli Gatti, D., Mauro, G., Bruce, C. G., Alberto, R., \& Joseph, E. S. (2012b). Sectoral imbalances and long run crises. In F. Allen, M. Aoki, J.-P. Fitoussi, N. Kiyotaki, R. Gordon, \& J. E. Stiglitz (Eds.), The global macro economy and finance (pp. 61-97). Houndmills, UK and New York: Palgrave. IEA Conference Volume No. 150-III.

Galbraith, J. K. (2012). Inequality and instability: a study of the world economy just before the great crisis. New York: Oxford University Press.

Greenwald, B., \& Stiglitz, J. E. (2010). A modest proposal for international monetary reform. In S. Griffith-Jones, J. A. Ocampo, \& J. E. Stiglitz (Eds.), Time for a visible hand: lessons from the 2008 World Financial Crisis (pp. 314-344). Oxford, UK: Oxford University Press.

Grossman, S., \& Stiglitz, J. E. (1976). Information and competitive price systems". American Economic Review, 66(2), $246-253$.

Grossman, S., \& Stiglitz, J. E. (1977). On value maximization and alternative objectives of the firm. Journal of Finance, 32(2), 389-402.

Herndon, T., Michael, A., \& Robert, P. (2014). Does high public debt consistently stifle economic growth? A critique of Reinhart and Rogoff. Cambridge Journal of Economics, 38(2), 257-279.

International Monetary Fund. (2010). "Will it hurt? Macroeconomic effects of fiscal consolidation. In In world economic outlook: recovery risk and rebalancing, 93-124. Washington, DC: International Monetary Fund Publication Services.

Jayadev, A., \& Konczal, M. (2010). When is austerity right? In boom, not bust. Challenge, 53(6), 37-53.

Korinek, A., \& Stiglitz, J. E. (2009). Dividend taxation and intertemporal tax arbitrage," with Anton Korinek. Journal of Public Economics, 93, 142-159.

Ostry, J. D., Berg, A., \& Tsangarides, C. G. (2014). Redistribution, inequality, and growth. International Monetary Fund Staff Discussion Note SDN/14/02, February.

Piketty, T. (2014). Capital in the twenty-first century. Harvard University Press.

Piketty, T., Saez, E., \& Stantcheva, S. (2014). Optimal taxation of top labor incomes: a tale of three elasticities. American Economic Journal: Economic Policy 2014, 6(1), 230-271.

Reifschneider, D., William, W., \& David, W. (2013). Aggregate supply in the United States: recent developments and implications for the conduct of monetary policy. In Paper presented at the 14th Jacques Polak Annual Research Conference. Washington, DC.

Stiglitz, J. E. (1969). Distribution of income and wealth among individuals. Econometrica, 37(August (3)), $382-397$.

Stiglitz, J. E. (1973). Taxation, corporate financial policy and the cost of Capital. Journal of Public Economics, 2(February), $1-34$.

Stiglitz, J. E. (2003). The roaring nineties. W.W. Norton.

Stiglitz, J. E. (2010). Freefall: America, free markets and the sinking of the world economy. WW Norton.

Stiglitz, J. E. (2012). The price of inequality. New York: W.W. Norton.

Stiglitz, Joseph E. 2015a. "Fed policy, Inequality, and Equality of Opportunity." Paper presented at the Ninth Biennial Federal Reserve System Community Development Research Conference, Washington, D.C. April 2015, to be published in Proceedings.

Stiglitz, J. E. (2015). The origins of inequality, and policies to contain it. National Tax Journal, 68(2), 425-448.

Stiglitz, Joseph E. 2015c. "New Theoretical Perspectives on the Distribution of Income and Wealth Among Individuals: Parts I-IV.” National Bureau of Economic Research Working Paper 21189-21192.

Stiglitz, J. E., Abernathy, N., Hersh, A., Holmberg, S., \& Konczal, M. (2015). Rewriting the rules of the American economy. pp. 2015. New York: W.W. Norton.

Stiglitz, J. E., \& Members of a UN Commission of Financial Experts. (2010). The Stiglitz Report: Reforming the International Monetary and Financial Systems in the Wake of the Global Crisis. New York: The New Press.

Stolper, W., \& Samuelson, P. (1941). Protection and real wages. Review of Economic Studies, 9-\#1, 58-73. 